\title{
Integration of Quality Function Deployment Method with Theory of Inventive Problem Solving in an Effort to Improve Clean Water Quality in Tirtanadi Regional Drinking Water Company Sunggal Medan Branch
}

\author{
Zubaidah Kartika Harahap ${ }^{1}$, Humala L. Napitupulu², \\ Meilita Tryana Sembiring ${ }^{3}$ \\ ${ }^{1,2,3}$ Universitas Sumatera Utara, Indonesia \\ Corresponding Author: Zubaidah Kartika Harahap
}

\begin{abstract}
Clean water is the main natural resource that is very important in human life because almost some of our daily activities require water such as bathing, drinking, washing clothes, cooking, etc. The purpose of this study is to analyze integration of quality function deployment method with theory of inventive problem solving in an effort to improve clean water quality in Tirtanadi Regional Drinking Water Company Sunggal Medan Branch. This research was conducted by using descriptive correlational method. The population of this research is the active customers of Tirtanadi Regional Drinking Water Company Sunggal Medan Branch. The number of active customers of Tirtanadi Regional Drinking Water Company Sunggal Medan Branch is 502,503 the number of subscribers in 2021. Because the number of customers is so large, the researcher draws the number of respondents using simple random sampling and random sampling of respondents based on the arrival of customers. Analysis of the results of data processing using the house of quality (HoQ) and the TRIZ method. From the results of the study obtained the following results that average level of importance, sorted from the highest value are the dimensions of turbidity, odor, color, taste, iron and residual chlorine. While the value of each dimension is $4.54 ; 4.33 ; 4.3 ; 4.21 ; 4.12 ; 4.00$. Performance level analysis The order of the average value of the perception level starting from the largest is
\end{abstract}

the dimensions of turbidity, odor, taste, color, iron and residual chlorine with a value of 3.90; $3.67 ; 3.65 ; 3.64 ; 3.56 ; 3.1$. The level of improvement is a comparison between the value expected by the company and the level of customer satisfaction with water quality. Sales Point consists of data processing, it can be seen that there are 9 attributes worth 1.5 which means that changes in these attributes have a major effect on the quality of clean water.

Keywords: Quality Function Deployment Method, Theory of Inventive Problem Solving, Clean Water Quality

\section{INTRODUCTION}

Clean water is the main natural resource that is very important in human life because almost some of our daily activities require water such as bathing, drinking, washing clothes, cooking, etc. So many people are worried when it is difficult to get this main natural resource. Some sources of clean water that can be used include sea water, groundwater (wells), mountain water, and rain water.

Research conducted by Sumantri \& Parwiyanto (2017), that clean water that can be used to meet human needs is clean water that is colorless, tasteless, free from organic and inorganic pathogens and germs. 
Zubaidah Kartika Harahap et.al. Integration of quality function deployment method with theory of inventive problem solving in an effort to improve clean water quality in tirtanadi regional drinking water company Sunggal Medan branch.

The requirements for drinking water quality refer to the Regulation of the Minister of Health of the Republic of Indonesia Number 492/MENKES/PER/IV/ 2010.

The regional drinking water company (PDAM) is one of the Regional Owned Enterprises (BUMD) owned by the North Sumatra Provincial government which is engaged in the business of providing clean water. This regional drinking water company (PDAM) sells clean water directly to the people of Medan.

Customer satisfaction is an important element so that the service company remains superior in facing current business developments as a company that provides and directly distributes clean water to the community, especially Sunggal areas for daily use.

Customer complaints from PDAM Sunggal Branch to the highest PDAM water quality are turbidity, color, residual chlorine, odor, iron and taste. As a drinking water supply business, PDAM Tirtanadi must provide satisfactory service to consumers even though in reality there are still customers who complain about the quality of clean water provided by PDAM.

Customer complaints about water quality based on interviews with the marketing department that the highest complaints were in December 2019, September 2019, October 2019, November 2019, August 2019 and July 2019.

Research conducted by Mulyana et al. (2016), that the level of customer satisfaction cannot be assessed from the point of view of the agency's assessment but must be viewed from the point of view of customer assessment.

Matters regulated in the Law of the Republic of Indonesia in 1999 concerning consumer protection, among the rights of consumers are stated in Article 4 that consumers have the right to be heard of opinions and complaints regarding the goods and or services used, as well as the right to be treated or served properly and honest and non-discriminatory.
According to Triastuti et al. (2018), quality function deployment (QFD) is used to determine the attributes of customer interest, measure the level of customer satisfaction and to determine strategies to improve product quality and to obtain customer perceptions and build a quality house. The results of this study indicate that the attribute of customer interest is information.

According to Putri and Oemar (2018), theory of inventive problem solving provides suggestions using contradiction solutions (39 Engineering Parameters TRIZ), constructs a contradiction matrix, and makes suggestions for improvements based on (40 Inventive Principles).

According to Silva and Martinez (2018), customer service can be improved by using a tool developed in Japan in the 60 s, using voice of customer called quality function deployment. QFD is very widely used by Japanese companies because it can understand customer desires which is used as a source of data for strategy and business. Theory of Inventive Problem Solving is a method used to find a solution to a problem, especially in the field of engineering, project-related problems, products/processes with innovative solutions. The integration of QFD and TRIZ can be more efficient in identifying customer needs and finding excellent problem solutions.

The purpose of this study is to analyze integration of quality function deployment method with theory of inventive problem solving in an effort to improve clean water quality in Tirtanadi Regional Drinking Water Company Sunggal Medan Branch.

\section{RESEARCH METHODS}

This research was conducted by using descriptive correlational method. Descriptive research method or also called survey research is a type of research that aims to describe systematically, factually and accurately about the facts and characteristics of a particular object or population. Correlational research is a study 
Zubaidah Kartika Harahap et.al. Integration of quality function deployment method with theory of inventive problem solving in an effort to improve clean water quality in tirtanadi regional drinking water company Sunggal Medan branch.

carried out with the aim of detecting the extent to which variations in a factor are related (correlated) with one or more other factors based on the correlation coefficient (Sinulingga, 2017).

Literature study was conducted to see the theories used in this research. Understand the concept by using supporting books and journals from the internet related to the problems and methods used (Tobing et al., 2018). Library research of reference sources is a form of research that uses library facilities by examining theoretical discussions from various books, articles, and scientific works related to writing (Pandiangan, 2018).

According Pandiangan et al. (2018) in Sugiyono, purposive sampling is the selection of samples based on certain characteristics that are considered to have relevance to the characteristics of the population that have been known previously. The population of this research is the active customers of Tirtanadi Regional Drinking Water Company Sunggal Medan Branch. The number of active customers of Tirtanadi Regional Drinking Water Company Sunggal Medan Branch is 502,503 the number of subscribers in 2021. Descriptive research is a type of research that aims to make a systematic, factual and accurate description of the facts and characteristics of the population of a particular area (Pandiangan, 2015). In this study, each element of the population is given the opportunity to be drawn as a member of the sample so that the method used for sampling is simple random sampling. Because the number of customers is so large, the researcher draws the number of respondents using simple random sampling and random sampling of respondents based on the arrival of customers.

Analysis of the results of data processing using the house of quality (HoQ) and the TRIZ method. House of quality (HOQ). This matrix describes the basic process in QFD, namely connecting what the customer wants (whats) and how the product will be produced to meet the customer's needs (hows) (Ginting, 2016). The TRIZ method is one way of solving or finding solutions to existing problems. The way it works starts with finding a problem, after that looking for a solution to the problem. TRIZ tries to find a solution to it. Finding a final solution to the problem that reduces the side effects of the solution.

\section{RESULT}

Based on interviews and collecting customer opinions using questionnaires, it can be seen that there are 19 attributes that are factors in customer assessment of the water quality of Tirtanadi Regional Drinking Water Company Sunggal Medan Branch. Complete data can be seen in Table 1 .

Table 1. Customer Requirement

\begin{tabular}{|c|c|}
\hline No.(1) & Information (2) \\
\hline \multicolumn{2}{|c|}{ Turbidity } \\
\hline 1. & The water is cloudy when used. \\
\hline 2. & $\begin{array}{l}\text { The water you use is dirty at certain times, for example } \\
\text { during the rainy season. }\end{array}$ \\
\hline 3. & $\begin{array}{l}\text { When opening the water faucet, there is soil or mud } \\
\text { when it comes out with water. }\end{array}$ \\
\hline 4. & $\begin{array}{l}\text { When opening the water faucet, there are grains of } \\
\text { sand/stone coming out with water. }\end{array}$ \\
\hline 5. & There is moss or dirt in the water. \\
\hline \multicolumn{2}{|l|}{ Smell } \\
\hline 6. & The water smells of rust. \\
\hline 7. & Water smells of chlorine from residual chlorine. \\
\hline 8. & Water smells like dirt or mud. \\
\hline \multicolumn{2}{|l|}{ Flavor } \\
\hline 9. & Water has a sour taste when used or consumed. \\
\hline 10. & Water tastes bitter when used or consumed. \\
\hline \multicolumn{2}{|r|}{ 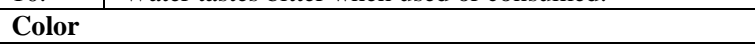 } \\
\hline 11. & The water color is brownish when used. \\
\hline 12. & The color of the water is yellow when used. \\
\hline \multicolumn{2}{|l|}{ Iron } \\
\hline 13. & The water smells sharp and pungent. \\
\hline 14. & Water feels slippery/rough when used. \\
\hline 15. & Yellow or rusty kitchen utensils when using tap water. \\
\hline 16. & $\begin{array}{l}\text { The bathroom when using Regional Drinking Water } \\
\text { Company. }\end{array}$ \\
\hline 17. & $\begin{array}{l}\text { Clothes are yellow when washed using Regional } \\
\text { Drinking Water Company. }\end{array}$ \\
\hline \multicolumn{2}{|c|}{ Clorine Rest } \\
\hline 18. & $\begin{array}{l}\text { Your eyes sting when using Regional Drinking Water } \\
\text { Company }\end{array}$ \\
\hline 19. & You experience skin irritation when using tap water. \\
\hline
\end{tabular}

All of the attributes in the Customer Requirements table, totaling 19 attributes, are the answers to the first problem formulation. These 19 attributes are factors that become the customer's assessment of 
Zubaidah Kartika Harahap et.al. Integration of quality function deployment method with theory of inventive problem solving in an effort to improve clean water quality in tirtanadi regional drinking water company Sunggal Medan branch.

the water quality of PDAM Tirtanadi Sunggal Branch.

Sunggal:

Water quality of PDAM Tirtanadi

1. From the average level of importance, sorted from the highest value are the dimensions of turbidity, odor, color, taste, iron and residual chlorine. While the value of each dimension is 4.54; $4.33 ; 4.3 ; 4.21 ; 4.12 ; 4.00$.

2. Performance level analysis the order of the average value of the perception level starting from the largest is the dimensions of turbidity, odor, taste, color, iron and residual chlorine with a value of $3.90 ; 3.67 ; 3.65 ; 3.64 ; 3.56 ; 3.1$.

3 . The level of improvement is a comparison between the value expected by the company and the level of customer satisfaction with water quality.

4. Sales Point consists of data processing, it can be seen that there are 9 attributes worth 1.5 which means that changes in these attributes have a major effect on the quality of clean water. There are 10 attributes that have a value of 1.2, meaning they have a small effect on clean water quality.

5. From the results of the TRS analysis, the attribute "Supervision of the company's raw water sources" with a value of $18.9 \%$ is the largest value, which means this item is considered the most important to get more attention to be followed up later.

6. The main priority problems to be solved using the TRIZ method These attributes are as follows:

a. The water is cloudy when used (5.86\%).

b. The water you use is dirty at certain times, for example during the rainy season $(5.70 \%)$.

c. When opening the water faucet, there is soil or mud when it comes out with water $(5.79 \%)$.

d. When opening the water faucet, there are grains of sand/stone coming out with water $(5.76 \%)$.

e. There is moss or dirt in the water $(5.81 \%)$. f. Water smells of chlorine from residual chlorine $(5.69 \%)$.

g. The water smells like dirt or mud $(5.72 \%)$.

$\mathrm{h}$. The color of the water is brown when used $(5.80 \%)$.

i. The color of the water is yellow when used $(5.97 \%)$.

\section{CONCLUSION AND SUGGESTION}

From the results of the study obtained the following results that average level of importance, sorted from the highest value are the dimensions of turbidity, odor, color, taste, iron and residual chlorine. While the value of each dimension is 4.54; $4.33 ; 4.3 ; 4.21 ; 4.12 ; 4.00$. Performance level analysis the order of the average value of the perception level starting from the largest is the dimensions of turbidity, odor, taste, color, iron and residual chlorine with a value of $3.90 ; 3.67 ; 3.65 ; 3.64 ; 3.56 ; 3.1$. The level of improvement is a comparison between the value expected by the company and the level of customer satisfaction with water quality. Sales Point consists of data processing, it can be seen that there are 9 attributes worth 1.5 which means that changes in these attributes have a major effect on the quality of clean water.

Based on the results of the improvement design obtained from the results of the study, the suggestions that need to be improved in relation to the results of the analysis and conclusions are as follows:

1. Companies need to focus on water quality treatment, because water is the main natural resource that is needed for daily life.

2. Periodic monitoring and checking of every process and machine of water treatment.

3. Work procedures must be based on standard operating procedures.

4. Actions that have not been taken seriously in water treatment, especially when it rains, where the water is more cloudy than usual. 
Zubaidah Kartika Harahap et.al. Integration of quality function deployment method with theory of inventive problem solving in an effort to improve clean water quality in tirtanadi regional drinking water company Sunggal Medan branch.

5. This study only consists of 6 variables of physical parameters from the voice of the customer, for further researchers it may be possible to continue to other variables and focus on technical problems in water treatment based on the research conducted by the author.

\section{Acknowledgement: None}

\section{Conflict of Interest: None}

\section{Source of Funding: None}

\section{REFERENCES}

1. Ginting, Rosnani. (2016). Quality Fuction Deployment. Medan: USU Press.

2. Mulyana, Herry,. Ruliana, Titin,. \& Suroso, Adi. (2016). Pengaruh Kualitas Pelayanan Terhadap Kepuasan Pelanggan Pada Perusahaan Daerah Air Minum Tirta Tuah Benua Kutai Timur Cabang Sangatta Utara. Jurnal Ekonomi, 5(1).

3. Pandiangan, Saut Maruli Tua. (2015). Analisis Lama Mencari Kerja Bagi Tenaga Kerja Terdidik di Kota Medan. Skripsi. Medan: Fakultas Ekonomi dan Bisnis, Program Studi Ekonomi Pembangunan, Universitas Sumatera Utara. https://www.academia.edu/52494724/Analis is_Lama_Mencari_Kerja_Bagi_Tenaga_Ker ja_Terdidik_di_Kota_Medan.

4. Pandiangan, Saut Maruli Tua. (2018). Analisis Faktor-faktor yang Mempengaruhi Penawaran Tenaga Kerja Lanjut Usia di Kota Medan. Tesis. Medan: Fakultas Ekonomi dan Bisnis, Program Studi Ilmu Ekonomi, Universitas Sumatera Utara. http://repositori.usu.ac.id/bitstream/handle/1 23456789/10033/167018013.pdf?sequence $=$ $1 \&$ isAllowed=y.

5. Pandiangan, Saut Maruli Tua, Rujiman, Rahmanta, Tanjung, Indra I., Darus, Muhammad Dhio, \& Ismawan, Agus. (2018). An Analysis on the Factors which Influence Offering the Elderly as Workers in Medan. IOSR Journal of Humanities and Social Science (IOSR-JHSS), 23(10), 76-79.
DOI: 10.9790/0837-2310087679. http://www.iosrjournals.org/iosrjhss/papers/Vol.\%2023\%20Issue10/Version -8/K2310087679.pdf.

6. Putri, As'ad \& Oemar. (2018). Perbaikan Kualitas dengan Menggunakan Metode TRIZ untuk Meminimasi Cacat pada Proses Pembuatan Al-Qur'an di PT Sygma Exa Grafika. Seminar Penelitian Sivitas Akademika UNISBA, 4(2). DOI: http://dx.doi.org/10.29313/ti.v0i0.13235.

7. Silva \& Martinez. (2018). Triz Integrated With QFD Applied in Automotive Valve Industry. DOI:10.15628/holos.2018.6669.

8. Sinulingga, Sukaria. (2017). Metode Penelitian. Medan: USU Press.

9. Sumantri, Bambang \& Parwiyanto, Herwan. (2017). Kualitas Pelayanan Perusahan Daerah Air Minum (PDAM) Kabupaten Sragen. Jurnal Wacana Publik USM, 1(1), 11-24.

10. Tobing, Murniati, Afifuddin, Sya'ad, Rahmanta, Huber, Sandra Rouli, Pandiangan, Saut Maruli Tua, \& Muda, Iskandar. (2018). An Analysis on the Factors Which Influence the Earnings of Micro and Small Business: Case at Blacksmith Metal Industry. Academic Journal of Economic Studies, 5(1), 17-23. https://www.ceeol.com/search/articledetail $? \mathrm{id}=754945$.

11. Triastuti, Ni Ketut Titi,. A.A.P., Agung Suyawan Wiranatha \& Luh Putu Wrasiati. (2018). Strategi Peningkatan Kualitas Produk Body Scrub Pt Bali Tangi Dengan Metode Quality Function Deployment. Jurnal Rekayasa dan Manajemen Agroindustri, 6(4).

How to cite this article: Harahap ZK, Napitupulu HL, Sembiring MT. Integration of quality function deployment method with theory of inventive problem solving in an effort to improve clean water quality in Tirtanadi regional drinking water company Sunggal Medan branch. International Journal of Research and Review. 2021; 8(9): 448-452. DOI: https://doi. org/10.52403/ijrr.20210957 